\title{
Indexes
}


Yuko Yokochi - 9789004269057

Downloaded from Brill.com04/26/2023 02:53:28PM via free access 


\section{INDEX TO THE INTRODUCTION}

Ādityabandhana (Vindhya): 13

Ādityarodhana (Vindhya): 7, 13

Agastya: 13, 63, 64

Agrāranya: 5, 6, 15

Alamkāradhārā: 5

Ambā: 26

Ambikā: 26

Amśuvarman: 3, 57

Andhaka: 25

animal- and bird-faced goddesses: 7 , 9

Anukramanikā: 11, 13, 21, 53

Arbuda: 7

Bābhravya (see Gālava and Pāñcāla): 19, 20

Bahumāṃsā: 72

Bāṇa: 364

Bengal: 3, 49

Bhadrakālī: 27, 28, 31

Bhalandala: 10, 22, 43, 44

Bhațtarāì: 25, 38, 39, 42, 45, 46, 53, $61,67,68,70,71,144$

Bisshcop, Peter: 50-52, 57, 62, 63

Brahmā: 5, 8, 9, 12-16, 18, 19, 23, $24,28,40,44,45,69,133$

Brahmadatta: 18, 19, 22

Brahmadhanvan: 15, 16, 18, 19, 21, 22

Cāmuṇụ̄ātype: 28, 31

Candịśataka: 25

caturmukhalinga: 9

Citraratha: 57

Consort Goddess: 31

Dakșa: 27

Daṇụaka (a metre): 25

Daśārṇa: 89

Deva: 45

Deveśā: 87
Deveśa: 139

Devì: 39, 40, 45, 85, 86, 100

Devīmāhātmya: 7, 10, 11, 366

Dhruvasangha: 57

Dindidi (a Gana): 16

Durgā: 31

Durgā-Kātyāyan̄i: 16, 19

editors of SP I: $34,42,48,54-56$

editors of SP IIA: 57, 59, 62, 63, 69

Gālava: 20

Gālava, Bābhravya: 20

Gaṇa: 7, 16, 27

Gaṇapati: 6, 16, 18

Gaṇas: 21

Gandhāra: 19

Ganeśvara: 8

Ganeśvaras: 44, 45

Gañgāprabhava: 6

Gaurī: 5, 12

Gaurīkūta: 12

Gaurīśamkara: 6

Gaurīśikhara: 5, 6, 8, 9, 12

Gayā: 52

Gokarna: 7, 8, 13-15

Gokarṇa-Māhātmya: 10, 13, 15, 22, 30,31

Grdhrakūteśvara: 52

Gupta icon (of Mahișāsuramardin̄̄):

57

Hāla: 10, 18, 97

Haribhadra: 27

Harimoto, Kengo: 59

Hārīti: 19

Harivaṃ́a: 6, 10, 13, 17, 27, 40

Hastivaktra: 25

hayaśiras: 20

Himālaya: 6, 8, 51

Indra: 9, 14, 48 
Jaratkāru: 16

Kālakarṇī: 28, 31

Kāmaśāstra: 20

Kāmasūtra: 20

Kampilya: 18

Kandurīka: 22

Karvan: 57

Kāṣțhakūṭa: 5, 17

Kātyāyanī: 7, 31

Kauśika Suparvan: 18

Kauśikī: 4, 5, 7-10, 12, 13, 15, 22, $24-31,57,133,376$

Kauśikī (River): 6

Kauśikī-Vindhyavāsinī: 3, 4, 6, 10, $19,24,26,27,29,31,57$

Kimnarī: 135

Koṭivarșa: 72

krama: 19, 20

Kramapāṭa: 20, 21

Kṛ̣ṇa: 6, 27

Kṛṣnā: 22

Kucakuṇda: 5

Kumbhakarna: 15

Lakșmīdhara: 4

Lakulīśa: 52

linga: 8, 13, 14, 57

Magadha: 52, 55

Magadhā: 52

Mahābhārata: 5, 6, 12, 44, 72

Mahālaya: 6

Māhātmya: 5-7, 13

Mahisa: 7, 9, 30, 57

Mahișāsuramardinī: 57

Mahodara (a Gaṇa): 16

Mānasa lake: 6

Matsyapurāṇa: 5, 19

Mirnig, Nina: 57

Mother of the world: 25, 26, 29, 30

Mother of the worlds: 30

Mothers: 12, 26-29, 31

Mothers of the world: 26

Mrtyu: 28

Mūka: 9

mūrtisthānam: 29

Naigameșa: 25, 26
Naikatungādhipeśvara: 51

Nandin: 20, 25, 31, 39

Nepal: 6, 11, 40, 49-54, 56-58

Nepāla: 51

Nidrā: 30

Nīlakuṇda: 5

Nīlalohita: 29

Niścīrā: 5, 6

Nisumbha: 6, 7, 9, 11, 29, 30, 41, 42, 65

Nisunda: 7-10

Pāñcāla: 19, 20, 22

Pāñcāla Bābhravya (see Gālava and Bābhravya): 20

Pañcacūụās: 25, 30, 31

Pañcāla: 18-22

Pañcāla (a country): 19

Pañcika: 19, 20

Pārvatī: 4-9, 12, 13, 15, 16, 18, 19, $22-31,39,40,44,45$

Pāśupata: 52, 55

Paśupati: 51, 57

Paśupatikșetra: 57

Pātaliputra: 52

Padmapurāṇa Sṛsțikhạ̣da: 5

Pitrkalpa: 17

Pitṛmāhātmya: 17

Prahasiteśvara: 52, 57

Puspabhadra: 57

Raghupañcikā: 71

Raghuvamśa: 71

Rāvana: 14, 15

Rc (Vāsisthī): 10, 17, 18, 21, 22

Revatī: 15

Śaiva Tantras: 57

Śākha: 26

Sanatkumāra: 7-10, 16-18, 29

Śatakratu: 14

Satī: 5, 26

seven Brahmins: 7, 8, 15-19, 21, 40

seven-Brahmins story: $17-22$

Śumbha: 7

śiksā: 19

Siva: 4-9, 12-17, 22-27, 29-31, 44, $45,48,50,140$ 
Śivadeva: 57

Skanda: 5, 12, 22, 24-26, 40

yogadharma: 18

Skanda cycle: 24

Yogeśvara: 18

Skandapurāṇa Māheśvarakhaṇḍ: 5

Somānandi: 16

Somanandin: 7, 8, 16, 18, 19, 22

Śrāddhakalpa: 17

Stanakunda: 5, 6

Sukeśa: 5, 16, 17

Sukeśa cycle: $5,16-18,21$

Sumbha: 6, 7, 9, 11, 29, 30, 41, 65

Sunda: $7-10$

Suśarman: 16

Svarṇākṣì: 5, 26

Śvetaketu, Auddālaka: 20

tapas: 6,16

Tāraka: 5

Tilottamā: 7, 9, 14

unicorn: 13,14

Upamanyu: 4, 5

Upanandi: 16

Vārānasī: 51, 57

Vātsyāyana: 20

Vibhīṣaṇa: 15

Vināyaka: 25

Vindhya: 5, 7-9, 12, 13, 22, 27, 29, 38,64

Vindhya subtype (of the Gupta iconic type of Mahișāsuramardin̄̄): 57

Vindhyavāsinī: 4, 13, 16, 19, 24, 25, $27,30,31$

Vindhyavāsin̄̄ Cycle: 4, 5, 7, 9-11, $14,19,22-30,59,61$

virgin: $24,26,29,30$

virginity: 30,31

Viśākha: 25, 26

Viṣnu: 13, 14, 20, 30, 31

Viśvāmitra: 6

Vṛtra: 14

Vyāsa: 4, 7-10, 16, 17, 21, 29

Warrior Goddess: 24, 25, 31

yoga: 18

Yogācārya: 19 